Landstat 画像データの主成分分析による水環境評価

\title{
Evaluation of Water Environment \\ by Using Principal Component Analysis \\ for Landscat Digital Data
}

\author{
村井俟治前四紛 \\ by Shunji Murai and Hiroshi Maeda
}

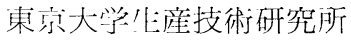

\begin{abstract}
ABSTRAC : The objective of the study is test the principal Tcomponent ana]ysis to obtain the comprehensive in dicator for evaluating the water environment with use of LANDSAT MSS digital data.

From the results of the analysis, much more detail information concerning the water environment can be obtained by the linear combinations of four bands, that by the single band of MSS 4 or MSS 5 band. This is because the digital data of the bend of MSS 6 , and even MSS 7 make a good deal of contribution to the water invironment.
\end{abstract}

\section{和文梗概}

地球資源衛生（LANDSAT）の MSS画像から，海: 面の水環境を見るには，一般に，4 4 バンド（0.5〜0.6 $\mu \mathrm{m})$ と 5 バンド $(0.6 \sim 0.7 \mu \mathrm{m})$ を用いればよいとさ れている。しかし, LANDSAT のディジタルデータ を詳細に検討して行くと， 6 バンド $(0.7 \sim 0.8 \mu \mathrm{m})$ も 水量環境に大きな影響を与えていることがわかった。 また，海岸や河口近くに括いては 7 バンド（0.8〜1.1 $\mu \mathrm{m})$ の影響もやや見られる。

これらの事から，本研究では，主成分分析の手法を 用いて，4つのバンドの線形結合により，水環境を評 価する指標を得ることを目的として，いくつかの数值 的な実験を試みた。主成分分析の結果，水環境を評価 するには，第 1 主成分と第 2 主成分を用いれば，それ ぞれのバンドを単独に用いるよりも，より詳細な情報 が得られることがわかった。

\section{1. はじめに}

わが国の沿岸の利用度はきわめて高いが，その水環 境は都市排水，工場排水，廃棄物の投衰，土砂流入な どによりいろいろな影響をらけている。沿岸の利用度 が高くなればなるほど，影響する要因は多様化する。 水環境を適切に把握, 評価し, さらに管理, 保全する ために必要な情報を与える手段の一つにリモートセン
シングの活用がある。その中で LANDSAT による MSSデータを水環境の評価情報として利用する研究が なされ，いくつかの可能性が報告されている。

本研究では，LANDSAT-2 号がとられた 1975年 9 月11日の名古屋地域のMSSデータ (ID. No. 2232-00 47300）を用い，陸部と厚い业のの゙ータを除いた水域 部に対応する 4 つのバンドのデータを取出し，これら のデータに主成分分析を適用して各主成分のもつ意味 を考察し，さらにそのスコアによって水環境を評価す ることを試みた。

水域部から得られる LANDSAT のデータは大別す ると，次に示す成分で構成された光がセンサーに入射 したものと考えられる。

(1) 水中に打壮る散乱光

（2）水面に拉村る天空反射光

（3）浅面，河川などの水底からの反射光

(4) 大気に和ける散乱光

これらの成分の大小は，水環境，大気および太陽光の 状態によって異なる。しかし，ここではそれぞれの成 分の影響を補正しないままで，オリジナルのデータを そのまま主成分分析にあてはめた。

\section{2. 使用データ}

2.1 水域部データの画像特性

図1. a , b 1975年 9 月11日にLANDSAT—2号が 


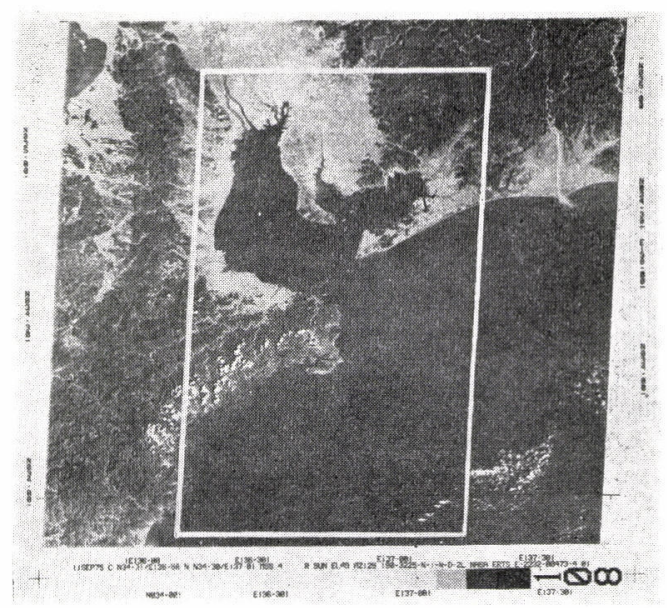

(a) 4 BAND

図 1 1975年9月11日

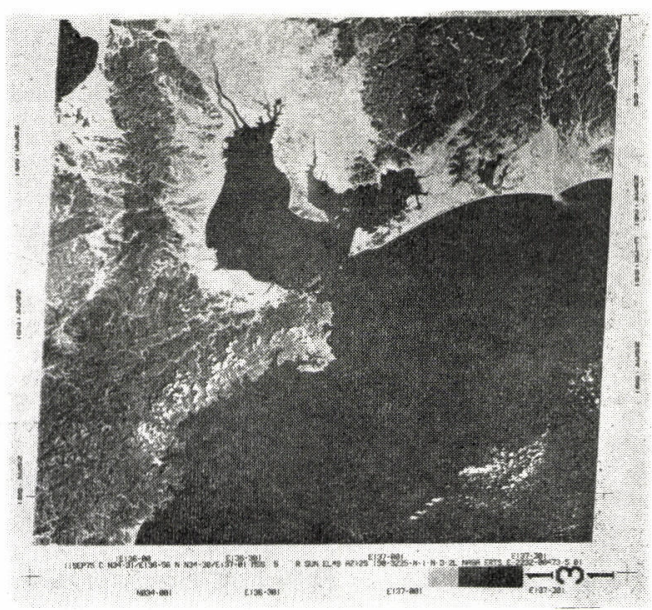

(b) 5 BAND

名古屋地域M S S バルク画像
とらえた名占屋城の 4 バンドと 5 バンドのバルク画像 である。

図1ａの白線で囲んだ地域（1632画素×1840ライン） をテスト領域とし，4，5，6，7バンドのデータを 用いた。

図 2 は, 対象地域の沿岸図である。この地域のデータ の各バンドごとに頻度をとると図 3 に示すようにな る。4バンドにおいてはあまり明確でないが，各バン ドとも 2 つのきなピークが見られる。特に， 7 バン ドに拈ける低いレベルの方のピークには顕著な傾向が みられ，0のレベル值をもつものが極端に多い頻度を 示している。7 7 バンドのレベル值が 0,1 である画素は 水域部に刘応するものである。レベル值が 2,3 につ いて地図上に対応させて及ると陸地近くの海, 入江, 湾内，河口，厚い县の周辺などに対応している。さら にレベル值が 4 の画素は，レベル值 $2 ， 3$ の画素と近 接しているが地図上では汪とんど陸地に対応してい た。このことから， 7 バンドにおけるレベル值が 3 以

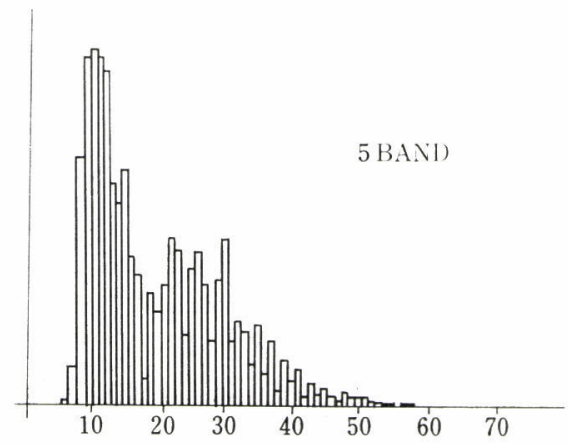

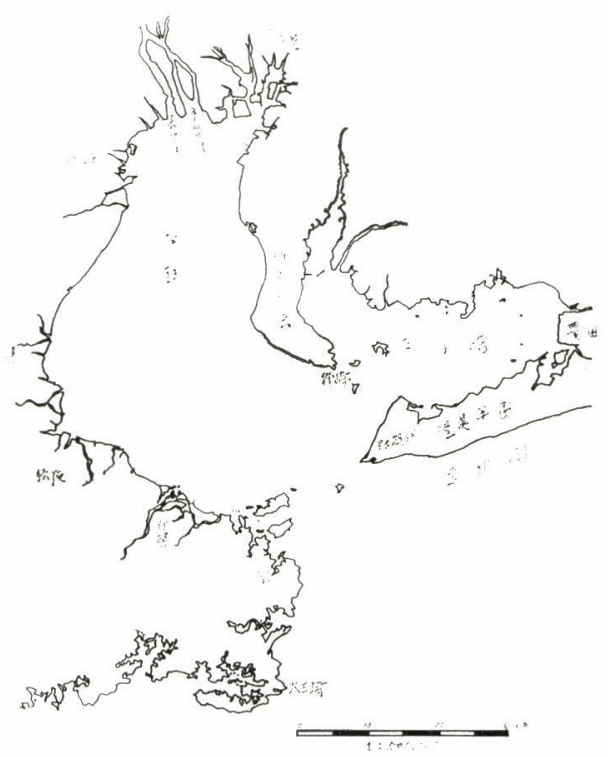

図 2 刘象地域の沿岸龱

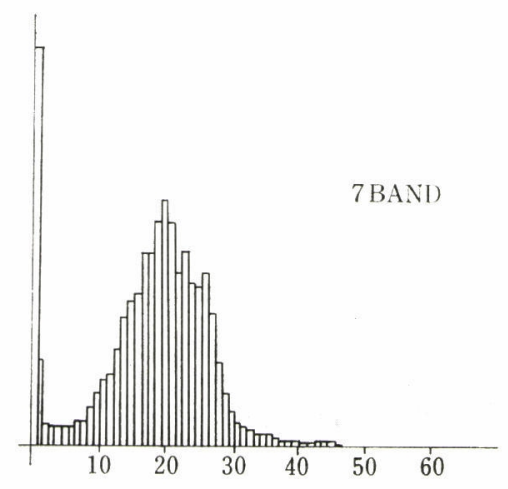



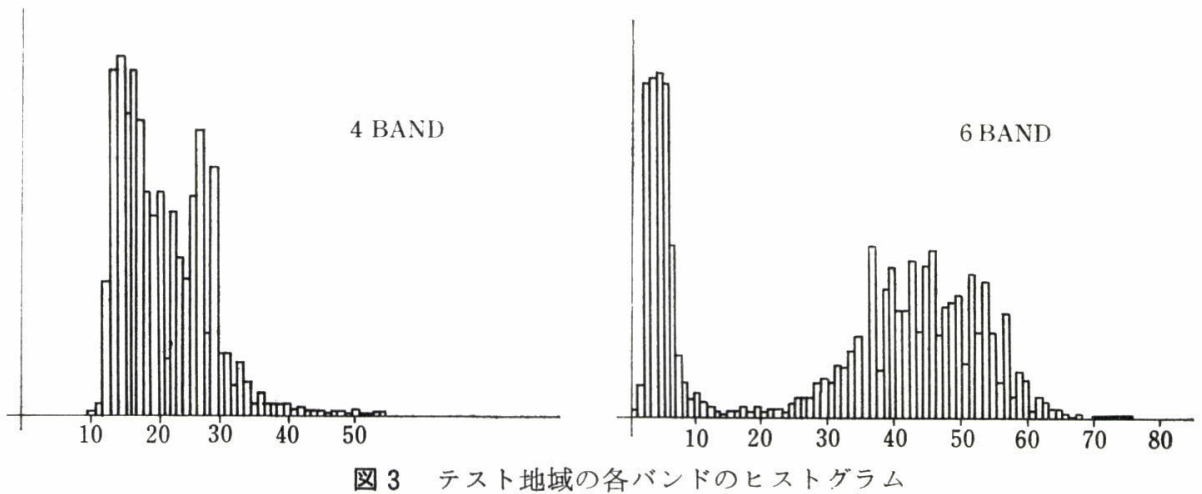

下の画素は水域であると判断してよいことがわかっ た。他の 3 つのバンドについて水域部のデータはほと んど低いレベル值のピーク周辺に分布している。各バ ンドの水域部のレベル值の幅は，4 バンドでは10〜32

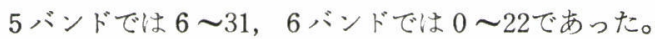
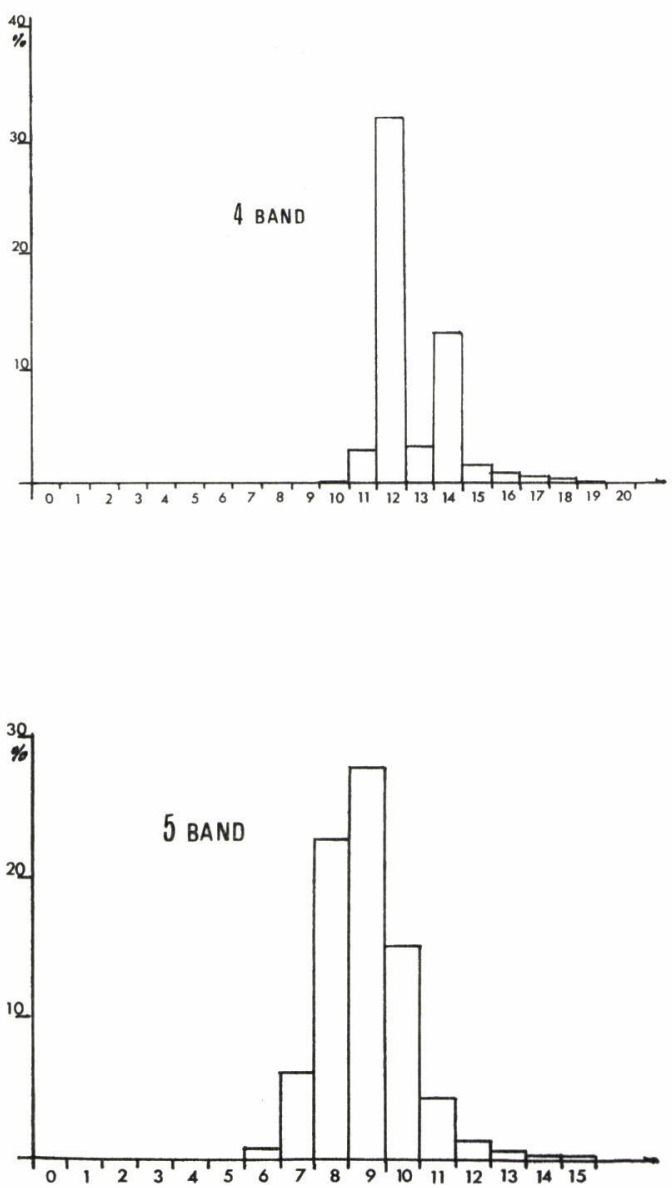

図 4 は各バンドの水域部の相対頻度を小゙す。また，図 5 は各バンドにお打る水域部を強調した画像を示す。

\section{2 サンプリングのケース}

対称地域より, 次の 4 つのケースに対して, 水域部 のデータを1000個以上サンプリングし主成分分析を行

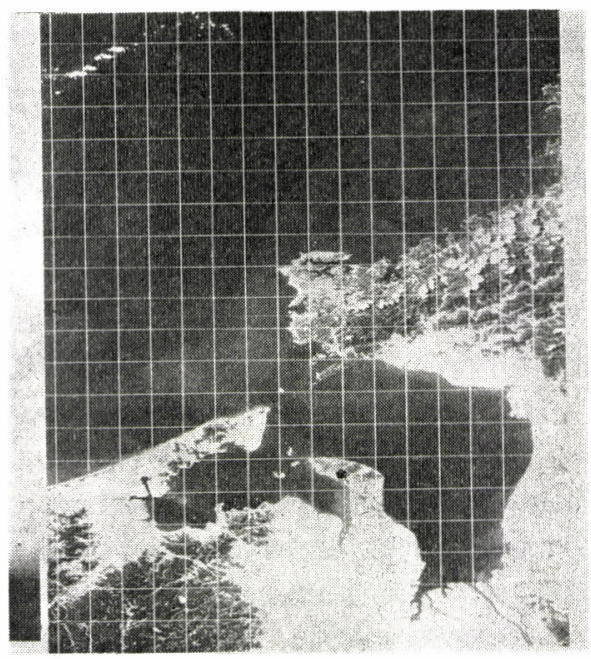



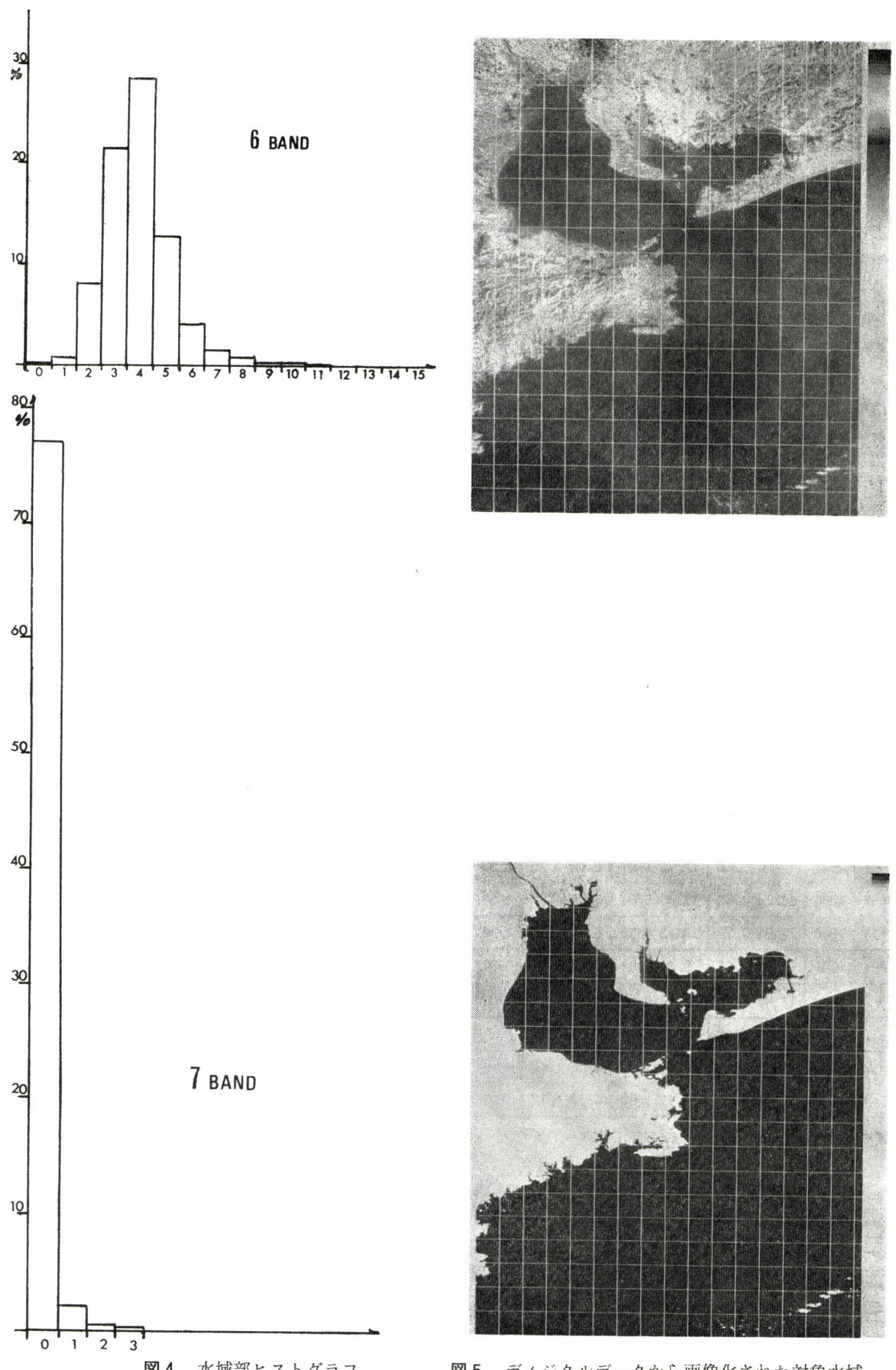

図 5 ディジタルデータから画像化された対象水域 
なった。

ケース 1：6ライン毎のラインに注目し，1ライ ン中の一定画素おきのデータを用いる。これはLANDSATデータが $6 つ の$ 検出器により収集されているの で，同じ検知器のみデータを用いることを目的とした ためである。表 1 に示されるように伊勢湾から大王崎 までの範囲で，ケース 1 はさらに異なる 3 つの検知器 に対応するケースに細分された。

ケース $2 ： 7$ バンドのレベル值 $0,1,2,3$ をも つ海域の画素を等個数サンプリングする。これは水域 に対応する 7 バンドの值の差の影響を見ようとしたも のである。ケース 2 は表 1 に示すように 3 つ異なる 場所に対応するケースに細分された。

ケース 3 ： ラインを省略しないで一定画素おきの データを用いる。これは，サンプリング地域の総合的 な差異を見ようとしたものである。ケース 3 は表 1 に 示すように，さらに 2 つ異なる場所に対応するケー スに細分された。

ケース 4 ：ケース 1 およびケース 3 の条件のもと でサンプリングしたデータ群のらち， 7 バンドを用い ないで主成分分析を行なう。これは 7 バンドの值がほ とんどの值であるので， 7 バンドの值の影響が期待で
きないと想定したためである。ケース 4 は表 1 に示さ

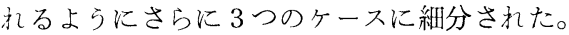

各ケースとも，1000〜 5000個のデータが対象地域の いろいろな場所よりサンプリングされている。

\section{3. 主成分分析の適用}

\section{1 主成分分析の手法}

各バンドのレベル值をそれぞれ $\mathrm{x}_{4}, \mathrm{x}_{5}, \mathrm{x}_{6}, \mathrm{x}_{7}$, 平均值 を $\overline{\mathrm{x}}_{4}, \overline{\mathrm{x}}_{5}, \overline{\mathrm{x}}_{6}, \overline{\mathrm{x}}_{7}$ ，標準偏差值を $\sigma_{4}, \sigma_{5}, \sigma_{6}, \sigma_{7}$ ，としたと きサンプリングされた画素の各バンド值を次の式で 正規化する。

$$
\mathrm{X} \mathrm{i}=(\mathrm{xi}-\mathrm{xi}) / \sigma \mathrm{i} \quad \text { ただし, } \mathrm{i}=4,5,6,7
$$
正規化されたデータXiを用いて，次の式で表わされる 線型結合をZ $\mathrm{j}$ するとき，Zjの分散を最大にし，さら に $\mathrm{Zj}_{\mathrm{j}} \mathrm{Zj}_{+1}$ が無相関であるよらに，係数 $\mathrm{aij}$ 求める。

$$
\begin{aligned}
& Z_{j}=a_{4} j \cdot X_{4}+a_{5} j \cdot X_{5}+a_{6} j \cdot X_{6}+a_{7} j \cdot X_{7} \\
& \text { ただし }, \quad j=1,2,3
\end{aligned}
$$

$\mathrm{Zj}$ は 4 つのバンドのレベル值の重みつき平妇となるか ら，4つのバンドの線型結合からなる総合特性值をあ らわす。 $\mathrm{Zj}$ は第 $\mathrm{j}$ 主成分のスコアとよばれる。

\section{2 主成分分析の適要}

\begin{tabular}{|c|c|c|c|c|c|c|}
\hline Case & $\mathrm{n}$ & $\sigma_{4}$ & $\sigma_{5}$ & $\sigma_{6}$ & $\sigma_{7}$ & 考 \\
\hline $1-1$ & 5000 & 13. 601.19 & 9.570 .87 & 3.471 .15 & 0.020 .17 & 伊勢湾から大王崎沖まで $\begin{array}{r}\mathrm{S} \mathrm{T}=500 \\
\mathrm{~S}=1200\end{array} \mathrm{~S}^{2}=12, \triangle \mathrm{P}=5$ \\
\hline $1-2$ & 5000 & 13.981 .07 & 9.691 .09 & $\begin{array}{lll}4.51 & 0.88\end{array}$ & 0.020 .17 & $\prime \prime \quad \begin{array}{r}\mathrm{S} \mathrm{T}=502 \\
\mathrm{~S}=1200\end{array} \triangle \mathrm{S}=12, \triangle \mathrm{P}=5$ \\
\hline $1-3$ & 5000 & 13.351 .27 & 9.341 .03 & 4.580 .93 & 0.090 .13 & 伊勢湾から伊良湖岬まで $\begin{array}{l}\mathrm{ST}=501 \\
\mathrm{~S}=700\end{array} \triangle \mathrm{S}=6 \quad \triangle \mathrm{P}=6$ \\
\hline $2-1$ & 1000 & 15.912 .65 & 12. $72 \quad 2.97$ & 8. 623.90 & 1.501 .12 & $\begin{aligned} \mathrm{ST} & =500 \\
\mathrm{~S} & =700\end{aligned}$ \\
\hline $2-2$ & 1000 & 16.744 .60 & 13.535 .01 & 8.524 .28 & 1.501 .12 & $\begin{array}{l}\text { 知多半島先より安乗岬まで } \mathrm{ST}=900 \\
\mathrm{~S}=600\end{array}$ \\
\hline $2-3$ & 1000 & 16.713 .79 & 13.134 .25 & 8.264 .44 & 1.501 .12 & 安乗岬より南側全域 \\
\hline $3-1$ & 5000 & $14.07 \quad 1.27$ & $9.02 \quad 1.44$ & 4.111 .00 & 0.010 .13 & 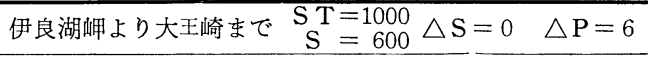 \\
\hline $3-2$ & 5000 & 13.041 .04 & 8.960 .99 & 4. 190.76 & 0.000 .02 & 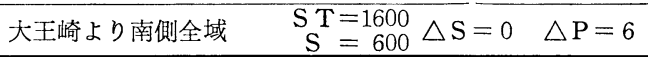 \\
\hline $4-1$ & 4511 & $12.67 \quad 1.03$ & 8.901 .31 & $\begin{array}{lll}4.46 & 0.89\end{array}$ & - & 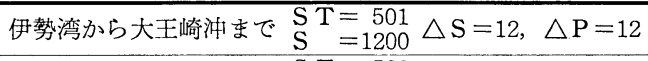 \\
\hline $4-2$ & 4515 & $12.88 \quad 1.33$ & 9.021 .00 & 4. $08 \quad 1.10$ & - & $\begin{array}{c}\mathrm{S} T=503 \\
\mathrm{~S}=1200\end{array}$ \\
\hline $4-3$ & 5000 & 13.551 .17 & 9. 211.00 & 4.131 .17 & - & $\begin{aligned} \mathrm{ST} & =500 \\
\mathrm{~S} & =1840\end{aligned} \mathrm{~S}=0, \triangle \mathrm{P}=100$ \\
\hline
\end{tabular}

表 1 は2.2に示した 4 つのースについて，主成分 分析に供したデータ群の要約を示し，表 2 はこれらの

\begin{tabular}{|c|c|c|c|c|c|c|c|c|c|c|c|c|c|c|c|}
\hline \multirow{2}{*}{ ケース } & \multicolumn{2}{|r|}{ 第 } & 主 & 分 & & \multicolumn{2}{|r|}{ 第 } & \multicolumn{3}{|c|}{ 主 成 分 } & \multicolumn{2}{|r|}{ 第 } & \multicolumn{3}{|c|}{ 主 成 分 } \\
\hline & $a_{4}$ & $a_{5}$ & $a_{6}$ & $a_{7}$ & $\alpha$ & $a_{4}$ & $a_{5}$ & $a_{6}$ & $a_{7}$ & 2 & $a_{4}$ & $a_{5}$ & $a_{6}$ & $a_{7}$ & $\omega_{3}$ \\
\hline $1-1$ & & 59 & 530 & 54 & & 06 & -0.192 & 0.255 & 3 & & 377 & 0.189 & 0.655 & $5-0$. & 0 \\
\hline & & & & & & & -0 & & & & & & & & \\
\hline 1 & & & & & & & -0 & & & & & 0 . & & 5 & \\
\hline $2-1$ & & 0.520 & & 477 & & & -0 & 28 & 0 . & & & -0.219 & 94 & $4|-0.565|$ & 97 \\
\hline $2-2$ & & 0.518 & .517 & & & & -0 & & & & & -0.008 & & $7-0$. & \\
\hline $2-3$ & & 0. & & 0.4 & & -0 & -0 & & 0. & & & 0.127 & & $5-0$. & 8 \\
\hline $3-1$ & & 0. & 5 & 0 & & 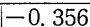 & -0 & .844 & -0.263 & & $-c$ & -0.289 & 0.844 & $4|-0.263|$ & \\
\hline & & & & $0.10 b$ & & & -0 & 0.017 & 0.988 & & & 0.275 & 0.388 & $8-0.088$ & \\
\hline $4-1$ & & 0.566 & 0.581 & & 62 & -0 & 0.822 & -0.449 & & 82 & & 0.059 & 0.678 & & 100. \\
\hline $4-2$ & & 0.605 & 0.563 & & 71.8 & -0.708 & 0.001 & 0.707 & & & -0 & 0.796 & -0.429 & & 100. \\
\hline $4-3$ & 0.572 & 0.603 & 0.526 & & 61.7 & -0.604 & -0.110 & 0.789 & & 88.5 & -0.555 & 0.769 & -0.317 & & 100. \\
\hline
\end{tabular}

表一1 サンブルデータの要約 ( $\mathrm{ST}$ ：スタートラインNo, $\mathrm{S}$ ：使用ライン数， $\triangle \mathrm{S}$ ：省略ライン数, $\triangle \mathrm{P}$ ：省略画素数） 
データ群を用いた主成分の係数值と寄与率を第 3 主成 分まで示した。

\section{3 主成分のスコア}

表 2 に示された主成分の係数のらち，ヶース 4 の 3 を用いテスト地域の全ての画素について，第 1 主成分

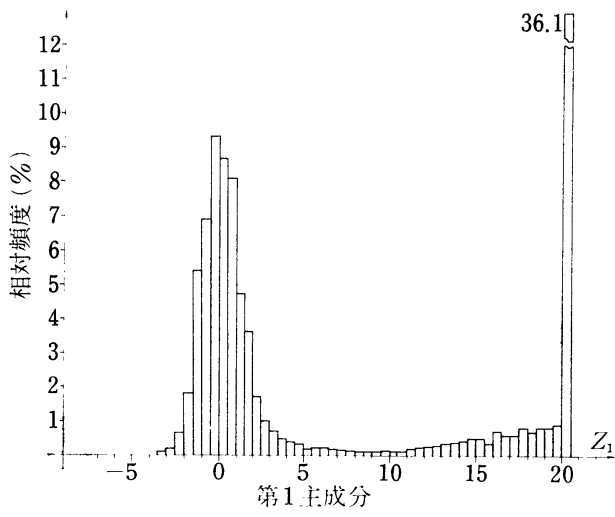

図 6 a Z 10ヒストグラフ

と第 2 主成分を算定した。図 6 は対象地域全域にわた って計算された第 1 主成分 $\left(Z_{1}\right)$ と第 2 主成分 $\left(Z_{2}\right)$ の ヒストグラムである。このヒストグラムで，スコア值 の大きいところにある頻度のピークが陸部に対応して いる。

図 7 は水域部のみに対して，第 1 主成分と第 2 主成 分を 2 軸とする 2 次元ヒストグラムを示す。成分のき ざみ幅は 0.5 であり，第 1 主成分はー $5.5 \sim 6.5$, 第 2 主成分はー4. 0 ～ 4.00 值の範囲となっている。頻度は 1000の単位で示され，1000以下の頻度は（．）で，頻 度なしは空白で示されている。

図 8 は主成分分析によって得られた第 1 主成分と第 2 主成分を画像化したものである。第 1 主成分につい てはー4.0〜6. 0 , 第 2 主成分についてはー3.0〜3.00 值の範囲をそれぞれ11等分に分けて，濃度配分して画 像化した。

表 3 は，バンド別の画像と主成分によって得られた 画像とを比較して，各種の物体がぞのように異なって 見えるかをしらべたものである。

\section{4. 結果の検討および考察}

以上に示した結果から，つぎのことが指摘できる。

（1）ケース 2 の結果などから，七ンサー特性の相異 によって同じ対象物でも，その主成分の係数值が異な る。したがって，分析を行なう場合，七ンサー特性の 相違に対するデータ補正が必要である。

(2) 第 1 主成分の係数の值はどのケースも約 0.5 近 辺である。したがって，スュア $Z_{1}$ は 4 つのバンドのス ペクトルエネルギーの和に比例している。水域部にお
いて， $Z_{1}$ が高い值を示すところは何らかの原因で污染 されているといえる。すなわち，第 1 主成分のスコア の值の大小は污染度に関係した指標といえる。

(3) 第 2 主成分は, ケースによって必ずしも統一的 な傾向を示さないが，全般的な傾向として赤外部（6

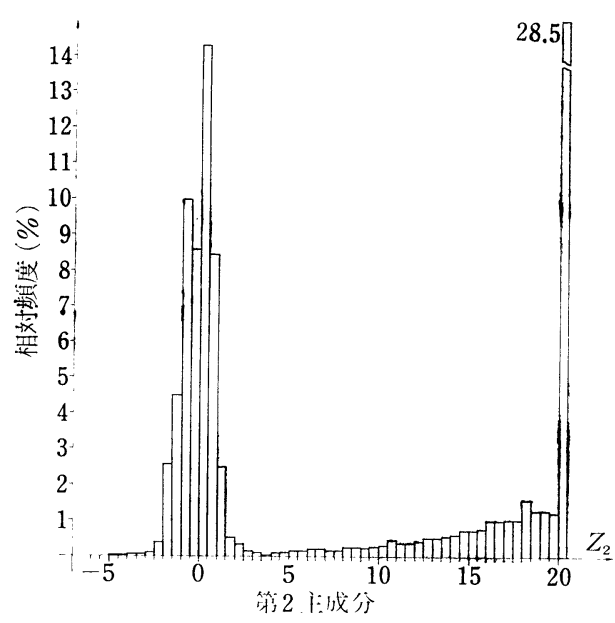

図 6 b Z Z 2 ヒストグラフ

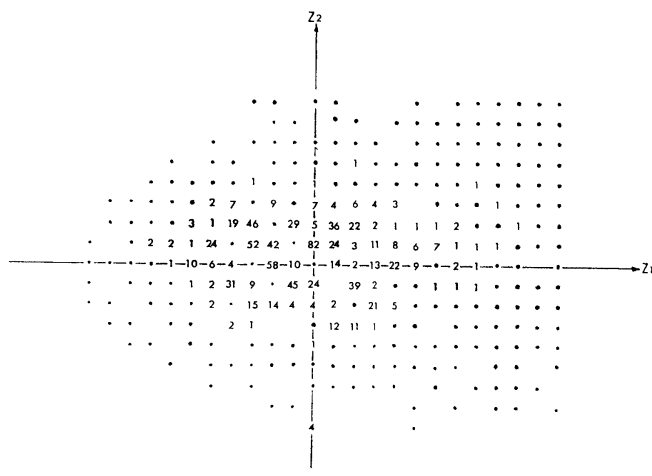

図 7 第 1 主成分 $\left(Z_{1}\right)$ 第 2 主成分 $\left(Z_{2}\right)$ にるる次元 ヒストグラフ

バンド， 7 バンド）に対する係数はプラスで，可視部 (4 ベンド， 5 バンド）に対する係数はマイナスであ り，赤外部と可視部の差を示している。スコア $Z_{1}$ の小 さいところは河口部, 沿岸開発の進んでいる水域部あ るいは干潟, 砂岸のある水域部などである。しかし， 沿岸開発の進んでいるところでもやや高い值をもって いるところがあり， $Z_{2}$ にいては $Z_{1}$ 関連づけて，そ の意味づけを行なう必要がある。

（4）水域部に扣汻る 7 バンドの值は赤外吸収によ り，0〜 3 までの 4 レベルの值しかもたず，そのうち 0 と 1 の值がほとんど全体の水域を占めている。 2,3 

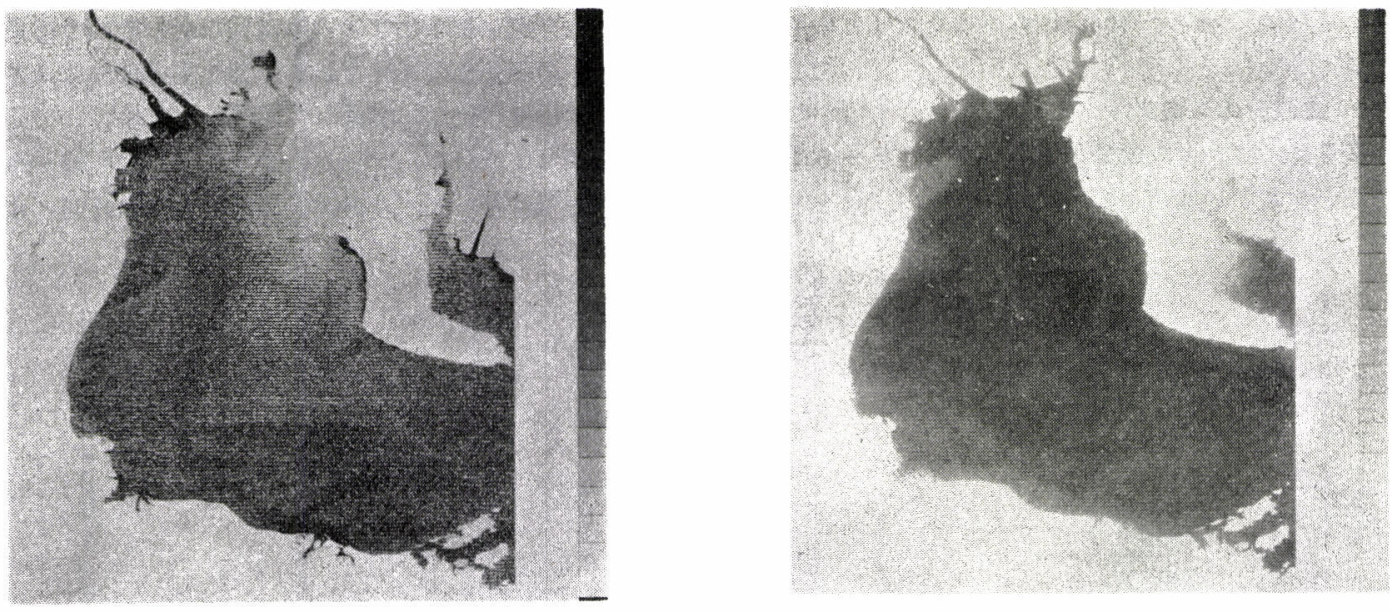

（a）伊勢湾

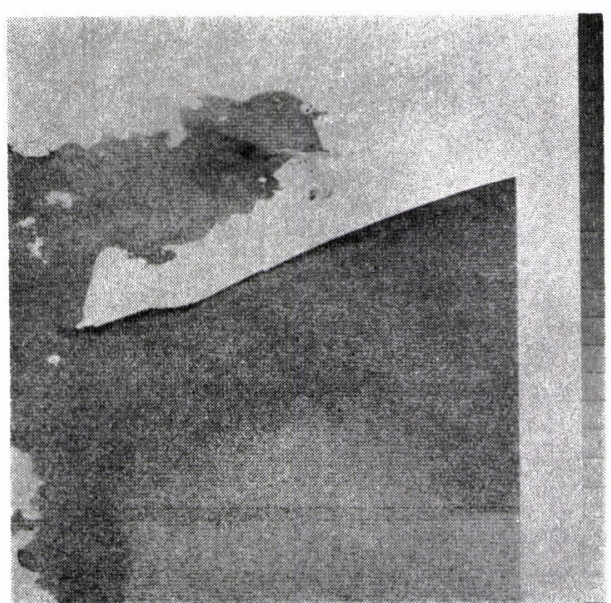

(b) 三河 湾

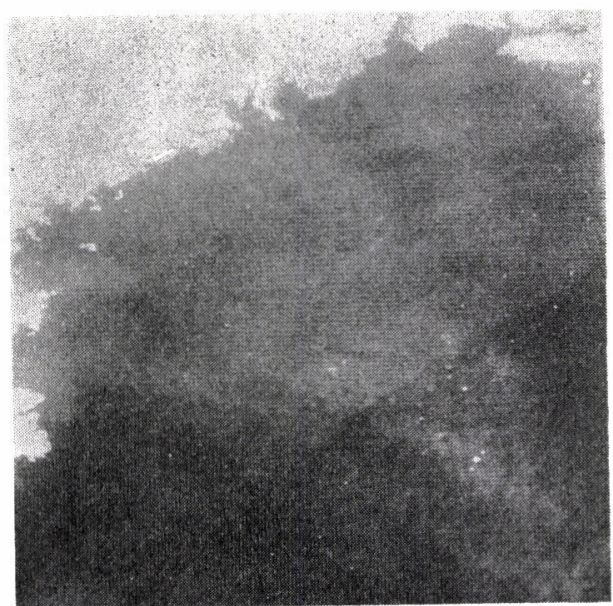

(c) 志 摩南西沿岸

図 8 第 1 主成分(左), 第 2 主成分(右)によるM S S 画像 
の值をもつ水域は, わずかに, 水域と㭝部あるいは厚 い雲との境界のみである。水域部に打ける 7 バンドの 值の変動が水環境の評価に対して, 有意義であるか否 かはセンサーの特性に対する補正を行なったのちに検 討すべきである。

(5) 第 3 主成分のスコアの值は，顕著な意味を有し ていない。第 2 主成分までの寄与率が約 $80 \%$ 以上ある
ことからも, 水環境の解析には第 3 主成分は考慮しな くてもよいと考えられる。

(6) 主成分分析にかけた画像の方が，バンド別の画 像よりより詳細で特徴的なパターンを示す。水域部 に対して，MSS データによる主成分分析を用いるこ とによって，水環境の指標を確立しうる可能性があ る。

表-3 MS Sバンド別画像亡主成分分析画像の対比

\begin{tabular}{|c|c|c|c|}
\hline 対象物体 & MS S バンド別画像 & 主成分分析画像 & 場 所 $の$ 例 \\
\hline 1. 全 体 & $\begin{array}{l}\text { 各バンドとも濃淡の変化がゆるや } \\
\text { かである。バンド間の濃淡パター } \\
\text { ソの相異がみられる。 }\end{array}$ & $\begin{array}{l}Z \text { Z 1, Z } 2 \text { の濃淡変化は急である。 } \\
Z \text { Z } 1 \text { とZ } 2 \text { の濃淡パターンは大き } \\
\text { く異なる。 }\end{array}$ & $\begin{array}{l}\text { · 木畺川河口 (長島海岸) } \\
\text { ·名古屋港 } \\
\text { ·知多半島, 師崎海岸南方沂 }\end{array}$ \\
\hline 2. 濁 水 & $\begin{array}{l}4 \text { バンドと } 5 \text { バンドでわかるが, } \\
\text { うすい雲, スモックとの分離はで } \\
\text { きない。 }\end{array}$ & $\begin{array}{l}Z \text { Z 亿おいては高い值であるがZ } \\
2 \text { においては低い值を示し, } Z 1 \\
\text { とZ2 の組合せにおいて判る }\end{array}$ & \\
\hline 3. 船 & $\begin{array}{l}\text { 4，5，6 バンドでは大きい船は } \\
\text { わかる }\end{array}$ & $\begin{array}{l}Z \text { Z 1において非常によくわかる } \\
Z \text { Z } 2 \text { に执いてややわかる }\end{array}$ & $\begin{array}{l}\text { ·伊勢湾内 } \\
\text { ·渥美半島太平洋側 } \\
\text { · 志摩半島太平洋側 }\end{array}$ \\
\hline 4. 航 跡 & 5バンドにおいてややわかる & $\begin{array}{l}Z \text { Z1Kおいてょくわかる } \\
Z \text { Z2は不明 }\end{array}$ & $\begin{array}{l}\text { ·渥美半島太平洋側 } \\
\text { ·伊勢湾中央 }\end{array}$ \\
\hline 5. 防波堤橋 & 5，6 バンドにおいてややわかる & $\begin{array}{l}Z 1 \text { においてきわめてよくわかる } \\
Z \text { Z2でわかる }\end{array}$ & $\begin{array}{l}\text { - 名古屋港高潮防波堤 } \\
\text { - 四日市港 } \\
\text { ·知多半島衣浦港 }\end{array}$ \\
\hline 6. 理立工事 & わかる & $\begin{array}{l}\text { わかる。ただし，Z１とＺ２の濃 } \\
\text { 淡はそれぞれ反転している }\end{array}$ & $\begin{array}{l}\text { ・四日市霞ケ浦埋立地 } \\
\text { ・伊勢市二見浦海岸 }\end{array}$ \\
\hline $\begin{array}{l}\text { 7. 雲 } \\
\text { スモッグ }\end{array}$ & $\begin{array}{l}\text { 厚い雲は, はっきりわかるが薄い } \\
\text { 雲およびスモッグは水の濃淡変化 } \\
\text { と混同される。 }\end{array}$ & $\begin{array}{l}Z \text { Z1飞和いて薄い雲などがバンド } \\
\text { 別画像と同じょうにわかる。 } \\
Z \text { Z 2 において, ほとんどあらわれ } \\
\text { ないのでとの組合せでわかる。 }\end{array}$ & $\begin{array}{l}\text { ·志摩半島太平洋上の㹃 } \\
\text { ·渥美半島太平洋上 }\end{array}$ \\
\hline $\begin{array}{l}\text { 8. 水域以外 } \\
\text { の分離性 }\end{array}$ & 7 バンドで陸部との区別ができる & $\begin{array}{l}Z \text { 1，Z } 2 \text { とも罪常によく分離さ } \\
\text { れる。 }\end{array}$ & - 陸部と水域部, 全体 \\
\hline
\end{tabular}

